\title{
KÜRESEL ĢEŞITLLLIK VE GLOBAL POLITIK ŞIDDET
}

\author{
Yrd. Doç. Dr. Sacht Hadl Akdedo \\ Adnan Menderes Üniversitesi \\ Nazilli Iktisadi ve Idari Bilimler Fakültesi
}

\section{Özet}

Bu çalışmada kültürel çeşitlilik, ulusal ve global sürtüşmeler ve kamu harcamalannın boyut ve kompozisyonu arasındaki ilişki ampirik olarak araşurılmuştır. Varolan kültürel çeşitlilik indeksleri kullanılarak, kültürel çeşitliliğin, sürtüşmelerin başlamasında ya da sürdürülmesi ve yoğunluğunda etkili olup olmadığı, 1980 ve 1990'I yıllar göz önüne tutularak, incelenmiştir. Bulgularımız, özellikle 1990'lı yıllardaki şiddet olaylarının başlaması ve devamında etnik farklılıklann önemli olduğuna işaret etmektedir. Politik şiddetin başlamasından öte, şiddetin yogunlugunu etkileyen faktörler de araşırılmışur. Burada 1980'li yıllarda sadece ekonomik faktörler önemli iken, 1990'lı yıllarda politik ve kültürel faktörler daha önemli olmuştur

Anahtar Kelimeler: Kültürel çeşitlilik, etno-lingüistik bölünme, modern politik ekonomi, politik siddet, kamu harcamaları.

\section{Cultural Diversity and Global Political Violence}

\section{Abstract}

This study investigates the relationship among cultural diversity, political violence and public expenditures. By using existing cultural diversity indices, it is empirically researched whether cultural diversity caused to start or intensify the political violence in the $1980 \mathrm{~s}$ and 1990s. It is found that especially in the 1990 s ethnic diversity was significantly taking a role in starting the violence or the intensity of it. Whereas economics factors were important to understand the intensity of violence in the 1980s, political and cultural factors were important in the 1990 s.

Keywords: Cultural diversity, ethno-linguistic fractrualization, modern political economy, political violence, public expenditures. 


\section{Kültürel Çeşitlilik ve Global Politik Şiddet*}

\section{Giriş}

Dünyanın son on beş yılı "ekonomik bütünleşme" diye adlandırılan bir döneme tekabül etmektedir. Bu on beş yıl içinde, milli gelirden alınan pay açısından, dünya mal ticaretinde, daha önceki dönemlere göre fark edilir bir artış olmuş; ülkeler bu dönemde aralarındaki mal alım satımını artırmışlardır. Dünya Bankası'nın veri seti Dünya Ekonomik Göstergeleri'ne göre dünya fiziki mal ticareti yani fiziki mal ihracat ve ithalat toplamının milli gelire oranı, son on beş yılda daha önceki dönemlere göre fark edilebilir bir artış göstermiştir. Bununla beraber ekonomik olarak bütünleşen dünya, politik olarak ayrısmalara uğramış; Yugoslavya'nın dağılmasından 6, Çekoslovakya'dan 2, eski Sovyetler Birliği'nden 15 yeni ve farklı devlet ortaya çıkmıştır. Bunlara Pasifik'teki Marshall adalarını, Micronesia ve Palau gibi Amerika'dan bağımsızlığını kazanan küçük adaları ve Namibya , Eritria gibi Afrika'daki yeni ülkeleri de eklediğimizde, 1990 ile 1993 yıllan arasında toplam 27 yeni ülkenin ortaya çıktığını görürüz. Son olarak, Endonezya'dan 2002 yılında bağımsızlığını kazanan Doğu Timur'u da bunlar arasına katabiliriz.

Bugün de dünyanın birçok bölgesinde ayrılıkçı/milliyetçi/etnik hareketler devam etmektedir. Yakın geçmişte, çeşitli ülkelerde yapılan referandumlar önemli sınır değişiklerine neden olmuş, örneğin Doğu Timur Endonezya'dan; Kuzey İrlanda, İskoçya ve Galler de İngiltere'den ayrılmıştır. İspanya'nın Bask

* Bu yazı 21. Maliye Sempozyumunda sunulmuştur. Özellikle Abuzer Pınar ve Ali Rıza Özdemir soru ve yorumlarıyla makaleye önemli katkı yapmışlardır. Kendilerine çok teşekkür ederim. Asistanlarımız Yasin Acar ve Hakan Hotunluoğlu bu çalışmanın hazırlık aşamasında çok titiz bir şekilde veri düzenleme işlemi yapmışlardır. Kendilerine teşekkürü bir borç bilirim. Recep Tekeli makaleyi baştan sona okuyarak çok değerli önerilerde bulunmuştur. Kendisine teşekkür ederim. Tabii ki bütün olası yanlışlardan ben sorumluyum. 
bölgesinde ayrılıkçı hareketler devam etmektedir. Gürcistan'da Abazalar ayrılıkçı hareketlerini sürdürmekte, Irak'ta farklı etnik ve dini gruplar iki üç farklı bağımsız devlet kurma amaçlarını gündeme getirmektedirler. Türkiye'de de ayrılıkçı etnik hareketler hala devam etmektedir. Endonezya'da Aceh bölgesi ayrı bir devlet kurmak istemèkte, 'Afrika'da birçok bölgede iç savaş ya da ayrılıkçı hareketler görülmektedir. Örneğin, Burundi'de Tutsi yönetimindeki devlete karşı Hutu'ların ayaklanmaları ve şiddetle karşılaşmaları sürmektedir. Cezayir, Berberi’lerin ayrılıkçı hareketleri nedeniyle, zaman zaman şiddetli karşılaşmalara sahne olmaktadır. Kamerun'da ayrılıkçı hareketler sürekli olmasa da devam etmektedir. Asya'da, Çin'in Sincan bölgesinde Uygur Müslümanlan tarafından sürdürülen ayrılıkçı hareketler devam etmektedir. Bu örnekler günümüzdeki ayrılıkçı hareketlerin bazılarını göstermektedir (Akdede, 2006).

Ayrılıkçı hareketler dışında, birçok ülkede uluslararası terörist faaliyetler de sürmekte ve özellikle 11 Eylül olaylan, terörist faaliyetlerin dünyayı ekonomik ve politik olarak çok fazla etkileyebileceğini göstermektedir.

Bu tür etnik çatışma, terörist faaliyetler ve ayrılıkçı hareketlerin yanında, ülkeler içinde sivil sürtüşmeler, politik başkaldınlar, gösteriler ve ayaklanmalar gibi politik istikrarsızhı yaratabilecek olaylar da varlıklarını sürdürmektedirler.

Modern politik ekonominin bir kolu, ülke büyüklük ve sayılarının içsel (endojen) olarak belirlendiğini vurgulayan makalelerle başlamıştır. 1990'lü yılların başında eski sosyalist ülkelerin dağılmasından ilham alan bu makaleler, uluslararası ticaretin liberalleşmesinin ülkeleri bölünmeye özendirdiğini çünkü siyasi sınırların artık ekonomik sınırlar olmaktan çıktığını vurgulamışlardır (Alesina/Wacziarg, 1998; Alesina vd., 1997) bu dönem makalelerin çok iyi bir özetini sunmaktadırlar.

Politik ekonominin bir başka önemli kolu, İkiz Kuleler'in vurulmasından sonra ortaya çıkmış ve bu olay, terörizmin politik ekonomisi, politik istikrarsızlık ve terörizm, terörizm ve ekonomik büyüme gibi konuların yeniden yoğun olarak araştırılmasına neden olmuştur (Minier, 2003; Montalvo, / Reynol-Querol, 2005; Addison/Murshed, 2005).

Bu çalışmada, buraya kadar ortaya koyduğumuz gelişmeler ışığında, sürtüşme ve şiddet olaylarının kültürel çeşitlilikle olan ilişkisi araştırılacaktır, ki bu konu dünyada ve Türkiye'de henüz yeni yeni araştırılmaya başlanmış, kültürel çeşitlilik ve sivil sürtüşmeler, özellikle 2005 yllının son aylarında, Fransa'daki olaylar aracılığıyla da popüler basında büyük yankı bulmuştur. Kısaca kültürel çeşitlilik ve kimlik ve bunların ekonomik ve politik değişkenlerle olan iliş̧isi politik ekonominin yeni bir kolunu oluşturmaya başlamıștır. Bu makale de bu alana katkı yapmak amacıyla yazılmıştır. 


\section{Literatür Özeti}

Modern politik ekonominin birçok farklı ana araştırma alanı bulunmaktadır. Bu ana alanlardan birisi ekonomik bütünleşme (economic integration) ve politik ayrışmaları (political disintegrations) incelemektedir; her ne kadar bu alanlar halen yöntemsel olarak sınıflanmayı bekliyor olsa da. Dolayısıyla, bu konuda, hem Türkiye'de hem de dünyada bir derleme makalesine ciddi bir ihtiyaç bulunmaktadır. Ekonomik bütünleşme-politik ayrışma ana alanının ilk kolunu, giriş bölümünde kısaca değinildiği gibi, sosyalist ülkelerin, ekonomik entegrasyonun yaşanmaya başladığı dönemde, çözülmesinin itham verdiği makaleler oluşturmaktadır (Alesinal Wacziarg, 1998; Alesina vd., 1997).

İkinci kolda , 11 Eylül olaylan sonucu ekonomistlerin bu olayların neden ve sonuçlarını anlamak için yazdıkları makaleler yer almaktadır (Easterly, 2000; Reynol-Querol, 2005; Li/Schaub 2004; Krueger/ Maleckova, 2002)

Üçüncui kolda ise, ki bu kol en yeni koldur, kültürel çeşitliliğin önemini ön plana çıkaran makaleler yer almaktadır. Kültürel çeşitliliği etnik, dilsel ve dinsel farklılıklarla ölçen çeşitli indeksler geliştirilmiş ve bunların bazı politik ve ekonomik değişkenler üzerindeki etkileri araştırılmıştır (Fearon, 2003; Alesina/La Ferrara, 2004; Annett, 2001;Gundlach/Matus-Velasco, 2000; Okediji, 2005). Bu çalışmada kültürel çeşitlilik, politik şiddet ve kamu harcamaları arasındaki ilişki araştırıldığından, özellikle bu alandaki literatür özetlenecektir.

Kültürel çeşitlilik, literatürde ya etnik-dilsel aynşma (ethno-linguistic fracturalisation) indeksi, sosyal ayrışma indeksi gibi birleşik (composite) indekslerle ya da sadece etnik ayrışma, dinsel ayrışma indeksleri gibi tekil indekslerle ölçülmektedir (Montalvoa/ Reynal-Querol, 2005; Okediji, 2005; Annett, 2001; Fearon, 2003). Bu grup içindeki makalelerin bir bölümünde kültürel çeşitliliğin, hangi indeks kullanılırsa kullanılsın, ekonomik kalkınma ve büyümeyi nasıl etkilediği araştırılmaktadır. Bu grup içinde politik istikranın ekonomik değişkenler üzerindeki etkisini araştıran makaleler de vardır ve bu literatür çok yeni değildir (Alesina vd.. 1996 Journal of Economic Growth makalesi). Bu grubun elimizdeki makale açısından ilginç ve ilgili olan makaleleri ise etnik, dilsel, dinsel farkhılıklar ve bu farklılıkların politik şiddet üzerindeki etkilerini araştıran makalelerdir (Fearon/Laitin, 2001, Krueger/Maleckova, 2002, Mousseau, 2001, Ellingsen, 2000; Collier/Hoeffler, 2006.). Kamu harcamala-rının kültürel çeşitlilikten nasıl etkilendiğini araştıran makaleler de, çok sayıda olmasa da, bu grubun içinde yer almaktadır (Tarzwell, 2003; Annett, 2001). 
Dolayısıyla, bu çalışmada kültürel çeşitlilik, politik şiddet ve kamu harcamaları arasındaki ilişki ampirik olarak araştırılacakır.

\section{Politik Şiddet Için Bir Ampirik Model}

Politik şiddet, ekonomik, politik ve sosyo-kültürel değişkenlerin bir fonksiyonu olarak modellenebilir. Buradaki politik şiddet, uluslararası bir savaşın dışında herhangi türden bir şiddet olarak modellenmiş veya bir grubun devlet gibi kurulu bir otoriteye karşı ya da iki farklı grubun birbirlerine karşı uyguladıkları bir güç olarak değerlendirilmiştir. Ampirik modelin tahmin edilmesi bölümünde daha detaylı açıklanacağı gibi, politik şiddet iç savaş, etnik sürtüşme veya çatışma, ülkeye karşı girişilen terörist faaliyetler gibi biçimler alabilir. Bir ülkenin başka bir ülkeyle olan savaşı bu makalenin kapsamı dışındadır ve modele dahil değildir. Politik şiddetin ekonomik, politik ve sosyokültürel nedenleri olabilir. Dolayısıyla, politik şiddet aşağıdaki gibi modellenebilir:

Politik Şiddet $=f($ ekonomik değişkenler, politik değişkenler, kültürrel değiskenler $)$

Bu modelleme ad hoc bir modelleme gibi görünse de, mikro temelden çok yoksun değildir. Politik şiddet, bir grup davranışı olduğu için bireysel fayda fonksiyonlarından yola çıkmak çok gerçekçi olmayacaktır. Bu makale, intihar eylemcilerinin davranıslarını bile bireysel bir eylem olarak görmemekte ve arkasında bir grup hareketi olduğunu varsaymaktadır. Şiddet bu şekilde bir grup hareketi olarak algılanınca, şiddetin başlama, bitirilme ve sürdürülme nedenleri bireysel olmaktan çok toplumsal olacaktır. Bu toplumsal nedenler de en genel ve toplulaştırılmış biçimde yukarıdaki bir numaralı denklemde sıralanan bağımsız değişkenlerdir. mışlardır:

Bağımsız değişkenler birer vektördür ve aşağıdaki gibi ayrıştınl-

\section{Ekonomik Değisskenler=(Kişi bassına düşsen milli gelir, Kişi başına düssen milli gelir $\left.{ }^{2}\right)$}

Politik Değişkenler=(Demokrasi, Demokrasi ${ }^{2}$,Demokratikleşme)

Kültürel Değişkenler=(Etnik çeşitlilik, Etno-Lingüistik-Dinsel çeşitlilik, Kültürel Ceşitlilik)

Dolayısıyla politik şiddet regresyon denklemi aşağıdaki gibidir. Bu tür modelleme siyaset bilimcilerin şiddeti modelleme biçimiyle de paralellik taşımaktadır (Moussaue, 2001). 
Politik Şiddet $=f\left(\right.$ Kişi başına düşen milli gelir, Kişi başına düşen milli gelir $\left.{ }^{2}, \ldots\right)$

Politik Siddet $=f\left(\right.$ Demokrasi, Demokrasi ${ }^{2}$, Demokratikleşme,..$)$

Politik Şiddet $=f($ Etnik çeşitlilik, Etno-Lingüistik-Dinsel çeşitlilik, Kültü̈rel Çeşitlilik,...)

$\mathrm{Bu}$ alandaki çalışmaların hemen hepsinde kişi başına düşen milli gelir, ülkenin gelişmişlik düzeyini gösteren bir değişken olarak alınmıştır. Bunun yanında, politik değişkenler olarak demokrasi, demokrasinin düzeyi ve demokratikleşme alınmıştır. Demokratikleşme, iki dönem arasındaki demokrasi düzeyinin nasıl değiştiğine işaret eden bir değişkendir. Kültürel değişkenler de etnik ve dilsel farklılıkları kapsayan indekslerle ifade edilmektedir. Politik şiddet iki farkh şekilde tahmin edilecektir. Ilk olarak, belli bir ülkede şiddetin başlama olasılığı Probit modelle tahmin edilecektir. Burada politik şiddet bir kukla değişken olarak modellenmiştir. Şiddetin başlaması ve devamı farklı olgular olduğu için farklı modellenmesi gerektiği düşüncesiyle, şiddetin yoğunluğuna ilişkin ikinci tür regresyonlar, saymaca (count) regresyonlar olarak modellenmiştir. Çünüu belli bir ülkede belli bir dönemde birden fazla şiddet başlamış ya da şiddetin yoğunluğu ve zamanı artmış olabilir. Bu durumda Probit ve OLS modelleri yanlı sonuçlar vereceğinden saymaca modeli tercih edilmiştir. Bunlara ek olarak, ülkeler çeşitli kamu harcamalarını ve demokratik yapılarını aynı zamanda tayin ettiklerinden bu değişkenlerin beraber tahmin edilebilmesi amacıyla, kamu harcamaları, şiddet ve kültuirel farklılıklar arasındaki ilişkiyi anlamak açısından, kamu harcamaları ve demokrasi regresyonlan için bir sistem tahmin yöntemi kullanılmıştır.

\subsection{Veri Kaynakları}

Bu çalışmada kullanılan veriler farklı kaynaklardan toplanmıştır. Politik şiddet başlangıcı için iki faklı data setinden yararlanılmıştır: Center for Systemic Peace (CSP) ve International Peace Research Institute, Oslo (PRIO). Şiddet başlangıcı regresyonu iki farklı on yıl için çekilmiştir, 1980 ve 1990'lı yıllar. Her bir on yıl ve herhangi bir ülke için şiddet başlangıcı yukarıda verdiğimiz iki farklı data seti göz önünde tutularak hazırlanmıştır.

Kültürel çeşitlilik değişkeni çeşitli indeksler kullanılarak ölçuilmüştür. Bu çalışmada, var olan bütün kültürel çeşitlilik indeksleri kullanılmıştır. Kültürel çeşitliliği etnik çeşitlilik (Montolvao/Reynal-Querolb, 2005), etno-lingüistik çeşitlilik (Annett, 2001), sosyal çeşitlilik (Okediji, 2005), dinsel çeşitlilik (Montolvao/Reynal-Querolb, 2005) ve ayrıca kültürel çeşitlilik (Fearon, 2003) olarak ölçen indeksler kullanılmuştır. 
Demokrasi değişkenleri Fredom House'dan alınmıştır. Fredom House, sivil özgürlükler (civil liberties) ve politik haklar ( political rights) indekslerini uzun zamandır birçok ülke için hazırlamaktadır. Bu indeksler l'den 7'ye kadar değer almaktadır; 7 en az demokrasiyi 1 ise en çok demokrasiyi temsil etmektedir. Bu makaledeki demokrasi regresyonunda kullanilan demokrasi indeksi, politik haklar ve sivil özgürlükler indekslerinin toplanması sonucu oluşturulan bir bileşik indekstir. Bu yöntem daha önce başka çalışmalarda da kullanılmıştır. Böylece maksimum değer 14, minimum değer de 2 olmaktadır. Böyle bileşik bir indeks oluşturmanın faydası, demokrasi değişkenini sadece bir indeksle karşılayabilme ve sıralanmış probit (ordered probit) dışındaki regresyonlarda da kullanabilme kolaylığıdır. Ayrıca politik istikrar, hukuka bağlllık (rule of law), sivil temsil (voice) gibi değişkenler de Dünya Bankası'ndan alınmıştır.

Kamu harcamaları regresyonlarında kullanılan nüfus, kişi başına düşen milli gelir, şehirleşme, dış ticaret hacmi, milli gelirin bir yüzdesi olarak kamu eğitim ve sağlık harcamaları, kamu tüketim harcamaları gibi hacimsel değişkenler de Dünya Bankası'nın Dünya Ekonomik Göstergeleri'nden (2005) alınmıştır.

\section{Regresyon Sonuçları}

Politik şiddetin belirleyicileri, 1980 ve 1990'lı yıllar ayrı ayrı analiz edilerek araştırılmıştır. Yukarıdaki iki numaralı denklemde politik şiddetin başlama olasılığı modellenmiştir. Bir probit regresyon olarak modellenen denklem 1980 ve 1990'lı yıllar için ayrı ayrı tahmin edilmiş ve regresyon sonuçları Tablo l'de verilmiştir. Tablo l'de ayrıca 2000'li yıllann başları için, politik istikrarın, ekonomik ve politik belirleyicileri analiz edilmiştir. Politik istikrarsızlık, politik şiddetten çok farklı bir değişkendir. Politik şiddet ölümle sonuçlanan sürtüşmelere işaret eden bir kavramdır. Politik istikrarsızlık ise daha hafif geçen sürtüşmeler ya da ölümle sonuçlanması gerekli olmayan çatışmalar, ayrıca grevler, gösteriler, v.b. politik ve ekonomik durumlan da kapsayan bir değişkendir. Şiddetin başlamasını belirleyen faktörlerle politik istikrarsızlığa neden olan faktörler farkh olabileceğinden, bu iki değişken ayrı ayrı modellenmiştir. Politik istikrar değişkeni sürekli bir değişken olarak inşa edildiği için, klasik en küçük kareler yöntemi tahmin için yeterli olmaktadır. Sonuçlar Tablo l'de verilmiştir. 
Tablo I Politik Siddet Başlantası ve Politik Istikrar

\begin{tabular}{|c|c|c|c|c|c|c|}
\hline \multirow[b]{2}{*}{ Değiskenler } & \multicolumn{2}{|c|}{$\begin{array}{c}\text { Şiddet Başlaması 80'lı } \\
\text { Yıllar } \\
\text { PROBIT }\end{array}$} & \multicolumn{2}{|c|}{$\begin{array}{c}\text { Siddet Başlaması } 90 \text { 'lı } \\
\text { Yıllar } \\
\text { PROBIT }\end{array}$} & \multicolumn{2}{|c|}{$\begin{array}{c}\text { Politik Ístikrar } 2002 \\
\text { OLS }\end{array}$} \\
\hline & Katsayt & Z-Stat. & Katsayt & Z-Stat. & Katsayu & t-Stat. \\
\hline Sabit & $-66.93^{* * *}$ & -3.09 & 2.04 & 0.08 & 0.56 & 0.19 \\
\hline Demokrasi & 1.87 & 0.51 & $-2,67$ & -0.55 & $-1.27^{*}$ & -1.96 \\
\hline Demokrasi $^{?}$ & -0.75 & -0.73 & 0.70 & 0.49 & $0.47^{* *}$ & 2.36 \\
\hline Demokratikleşme & 0.08 & 0.52 & $0.34 * *$ & 2.52 & & \\
\hline GSMH( $80-89)$ & $13.50 * * *$ & 2.59 & & & & \\
\hline $\operatorname{GSMH}(80.89)^{2}$ & $-0.85^{* * *}$ & -2.66 & & & & \\
\hline $\operatorname{GSMH}(90-99)$ & & & .0 .19 & -0.03 & -0.20 & -0.23 \\
\hline $\operatorname{GSMH}(90-99)^{2}$ & & & -0.08 & -0.18 & -0.005 & -0.10 \\
\hline Etnik Çeşitlilik. & 1.15 & 1.41 & $1.46^{* *}$ & 2.04 & $-0.12^{*}$ & -1.97 \\
\hline Nüfus(80-89) & $0.91^{* * *}$ & 3.87 & & & & \\
\hline Núfus(90-99) & & & $0.51^{* * *}$ & 2.78 & -0.007 & -0.17 \\
\hline Et.Çes ${ }^{*}$ Demokrasi ${ }^{2}$ & -0.27 & -1.53 & -0.08 & -0.49 & -0.01 & 0.56 \\
\hline Dıs Ticaret & & & & & $0.29 * * *$ & 2.66 \\
\hline Demok $^{2 * E t . ~ C ̧ e s ̧ . . ~}$ & 0.02 & 0.87 & $-0.12^{*}$ & -1.88 & & \\
\hline Sehirleşme & & & & & $0.32^{* *}$ & 2.16 \\
\hline Egitim & & & & & -0.18 & -1.40 \\
\hline Şiddet 2000 & & & & & $-0.74 * * *$ & -4.31 \\
\hline Sivil Temsil & & & & & $0.54^{* * *}$ & 2.95 \\
\hline Hukuka Bağlılık & & & & & $0.45^{* * *}$ & 3.44 \\
\hline Bölgesel Kuklalar & Evet & & Evet & & Evet & \\
\hline McFadden $\mathrm{R}^{2}$ & 0.34 & & 0.36 & & 0.79 & \\
\hline Gözlem Sayısı & 105 & & 106 & & 106 & \\
\hline
\end{tabular}

Not: z istatistikleri parantez içinde gösterilmiştir, $* 0<0.1, * * 0<0.05, * * * 0.01$

Tablo 1'den de görüldüği gibi, 1980'li yıllarda politik şiddeti başlatan faktörler arasında ülkelerin etnik çeşitliliği ya da heterojen yapısı çok önemli olmamaktadır. Ülkelerin demokratik yapısı ya da demokratikleşmenin düzeyi 
de bu dönemdeki politik şiddeti etkilememektedir. Diğer bir deyişle, daha çok başlangıç demokrasisi ya da daha çok demokratikleşme politik şiddeti istatistiksel olarak anlamlı bir şekilde etkilememektedir. Dolayısıyla bu dönemdeki politik şiddet daha çok demokrasiyle ya da daha çok etnik homojenlikle azaltılabilecek bir niteliğe sahip değildir. Demokratikleşme ile etnik farklılık değişkeninin etkileşimi de politik şiddet üzerinde etkili olmamaktadır. Başka bir deyişle, demokratikleşmenin çok olduğu toplumlardaki, etnik farklılıkların politik şiddeti azaltıcı ya da artırıcı bir etkisi olduğu gözlenmemektedir.

Regresyon sonuçlanndan, ülkelerin ekonomik gelişmişlik düzeylerinin, politik şiddet üzerinde etkili olan tek faktör olduğunu gözlemekteyiz. Tablo l'de kişi başına düşen gelirin düşuik olduğu ülkelerde politik şiddetin düşük, orta gelirli ülkelerde yüksek ve zengin ülkelerde tekrar düşük olduğunu gözlemekteyiz. Politik şiddet ile ekonomik gelişmişlik düzeyi arasında doğrusal olmayan bir ilişki vardır. Çok fakir ülkeler, politik şiddeti başlatamayacak ya da sürdüremeyecek kadar düşük gelirlidirler. Çok zengin ülkelerde de politik şiddetin ekonomik ve politik maliyeti çok yüksek olduğu için, şiddet sürdürülmüyor olabilir. Nüfus değişkeni de genellikle politik şiddet regresyonlarına dahil edilmiştir (Mousseau, 2001). Tablo l 'de kalabalık ülkelerde daha çok şiddet başladığını gözlemekteyiz. Bu durum etnik farklılıktan kaynaklanmamaktadır çünkü regresyon etnik farklılık için zaten kontrol edilmektedir. Bu noktanın daha detaylı araştırılması gerekmektedir. Ancak bu, kendi başına ayn bir makalenin konusunu oluşturmaktadır.

Tablo 1'de 1990'lı yıllarda şiddet başlama olasılığının belirleyicilerini de gözlemekteyiz. 1990'lı yıllarda, etnik farklılığ çok olan toplumlar, daha çok politik şiddet başlamasına maruz kalmışlardır. Bu yıllarda 1980'li yıllann tam aksine ekonomik gelişmişlik düzeyi hiç etkili olmamaktadır. Ülkelerin fakir ya da zengin olması politik şiddeti başlatmada istatistiksel olarak, 1990'lı yıllarda hiç etkili olmamaktadır. Demokratikleşmenin artığı toplumlarda ise ortalama politik şiddet başlama sayısı azalmaktadır. Dolayısıyla bu yıllarda demokratikleşme önemli bir faktör olarak belirmektedir. Eğer politik şiddetin azalması isteniyorsa, etnik farklılıkların ortadan kaldırılmasından öte (ülkelerin etnik temelli bölünmesi ya da etnik temizlemeden öte), daha çok demokratikleşme politikalarına öncelik verilmelidir çünkü hiçbir ülke saf/arı ırk temelli kurulamamaktadır. Bu durum interaktif terimin istatistiksel olarak anlamlı olmasından da ortaya çıkmaktadır. Demokratikleşmenin ve etnik çeşitliliğin çok olduğu toplumlar, daha az sayıda şiddet başlamasına sahne olmuşlardır. Bu durum sağduyuya uygun görünmektedir. Farkhı etnik gruplar, çok demokratik toplumlarda şiddet başlatma olasılığını her bakımdan çok maliyetli görmekte ve bir anlamda politik ve ekonomik rahatların bozmak 
istememektedirler. Var olan demokratikleşme ortamın kendi lehlerine kullanma eğilimine girmektedirler.

Tablo l'de ayrıca 2002 yılındaki politik istikranın olası belirleyicileri de analiz edilmektedir. Ülkelerin politik istikrarı onlann demokratik yapılarıyla doğrusal olmayan bir ilişki göstermektedir. Demokrasinin çok düşük ve çok yüksek olduğu ülkelerde daha çok politik istikrar gözlenirken, ortalama demokrasiye sahip ülkelerde de daha az politik istikrar gözlenmektedir. Bu anlamsız bir bulgu değildir; demokrasinin düşük olduğu diktatörlükler de politik istikrara sahiptir çünkü hiçbir muhalif eyleme izin verilmemektedir. Tablo l'de etnik farklılığın politik istikran azalttığını gözlemekteyiz çünkü bu değişkenin katsayısı istatistiksel olarak anlaml ve negatiftir. Etnik farklılıkların, politik istikrarsızlığın kaynağı olabileceği pratikte gözlemlenen bir olgudur ve iktisat sezgisine de uygundur.

Politik şiddetin başlama olasılığının araştırılması yanında, şiddetin yoğunluğu/derecesini belirleyen faktörlerin incelenmesi de önemlidir. Bu analiz için, yukarıdaki denklem 2, durumun dinamik yapısına uygun olarak adapte edilmiştir. Şiddetin derecesini belirleyen faktörlerin başında, şiddetin zaman bakımundan uzunluğu ve ülkenin maruz kaldığı şiddet olayı sayısı gelmektedir; bir uilkede belli bir dönem içinde birden fazla şiddet olayı meydana gelebilir. Genellikle Hindistan, Pakistan, Çin, birçok Ortadoğu ve Afrika ülkesi için durum böyledir. Bu süreç içindeki ekonomik ve politik değişkenlerdeki değişmeler şiddetin derecesini etkileyebilir.

Ekonomik değişkenlerin başında ekonomik büyüme gelmektedir. Ekonomik büyüme gelirlerin artması ve zenginleşmek anlamına gelmektedir. Ekonomik büyüme literatüründen bilindiği gibi, ekonomik büyüme, gelir dağılımında düzelmeyi garanti etmemektedir. Gelir dağılımda adaletsizlikler olabilir, ancak gelirler artıyorsa en fakirlerin bile yaşam standardı yükseliyor olabilir. Bu durumda artan gelir ve yaşam standardı, şiddetin derecesinin azalmasına neden olabilir; çünkü politik şiddetin artması büyümeyi tehlikeye atabilir. Bu bir bağlantı kanalı olabilir. Ayrıca politik değişkenler de şiddetin yoğunluğunu etkileyebilirler. Örneğin daha çok demokratikleşme daha az şiddet anlamına gelebilir, her ne kadar daha çok demokratikleşme daha çok politik şiddet anlamına da gelebilmekte ise de. Demokrasilerde örgütlenme ve gösteri hürriyetleri gibi birçok hak ve özgürlük, daha çok şiddet olayının meydana gelmesine de neden olabilir. Bu tamamen ampirik bir sorundur çünkü teori her iki durum için de belirli bir mantık sunmaktadır. Aşağıda Tablo 2, iki farklı kaynaktan (CSP ve PRIO) oluşturulan verilerden yararlanarak hazırlanmıştır ve bu konularda yorum yapmamızı kolaylaştıracak regresyon sonuçlanını sunmaktadır. Şiddet yoğunluğu/derecesi bir saymaca regresyon olarak modellenmiştir. 
Tablo 2 :Şiddetin Yoğunluğu

\begin{tabular}{|c|c|c|c|c|c|}
\hline \multicolumn{3}{|c|}{ Politik Şiddet Yogunluğu $1980^{\circ}$ li Yıllar } & \multicolumn{3}{|c|}{ Politik Şiddet Yoğunluğu 1990'li Yıllar } \\
\hline Değişkenler & $\begin{array}{l}\text { Count Model } \\
\text { PRIO Datası }\end{array}$ & $\begin{array}{l}\text { Count Model } \\
\text { CSP Datası }\end{array}$ & $\begin{array}{l}\text { Count Model } \\
\text { Değişkenler }\end{array}$ & $\begin{array}{l}\text { Count Model } \\
\text { PRIO Datası }\end{array}$ & $\begin{array}{l}\text { Count Model } \\
\text { CSP Datası }\end{array}$ \\
\hline Sabit & $\begin{array}{c}-16.01 * * * \\
(-4.63)\end{array}$ & $\begin{array}{l}-14.54 \\
(-1.41)\end{array}$ & Sabit & $\begin{array}{c}-15.82 * * * \\
(-3.95)\end{array}$ & $\begin{array}{l}-14.14 \\
(-0.60)\end{array}$ \\
\hline Demokrasi & $\begin{array}{l}1.02 \\
(1.36)\end{array}$ & $\begin{array}{c}1.05 \\
(0.65)\end{array}$ & Demokrasi 90 & $\begin{array}{l}2.56^{* * *} \\
(-2.75)\end{array}$ & $\begin{array}{c}0.91 \\
(0.11)\end{array}$ \\
\hline Demokrasi $^{2}$ & $\begin{array}{c}0.07 \\
(0.35)\end{array}$ & $\begin{array}{c}-0.53 \\
(-0.90)\end{array}$ & Demokrasi $90^{2}$ & $\begin{array}{c}-0.76 * * * \\
(-3.28)\end{array}$ & $\begin{array}{c}-0.53 \\
(-0.26)\end{array}$ \\
\hline $\begin{array}{l}\text { Demokratikle } \\
\text { sme }\end{array}$ & $\begin{array}{c}0.04 \\
(1.09)\end{array}$ & $\begin{array}{c}0.03 \\
(0.45)\end{array}$ & Demokratikleşme & $\begin{array}{l}0.039 \\
(1.22)\end{array}$ & $\begin{array}{c}-0.04 \\
(-0.41)\end{array}$ \\
\hline $\begin{array}{l}\text { GSMH(80- } \\
89)\end{array}$ & $\begin{array}{l}2.10^{*} \\
(2.34)\end{array}$ & $\begin{array}{l}3.58 \\
(1.31)\end{array}$ & GSMH 90-99 & $\begin{array}{l}2.53^{* *} \\
(2.33)\end{array}$ & $\begin{array}{c}1.74 \\
(0.30)\end{array}$ \\
\hline $\begin{array}{l}\text { GSMH }(80- \\
89)^{2}\end{array}$ & $\begin{array}{l}-0.13^{*} \\
(-2.22)\end{array}$ & $\begin{array}{l}-0.27 \\
(-1.54)\end{array}$ & GSMH $90-99^{2}$ & $\begin{array}{l}-0.17^{* *} \\
(-2.47)\end{array}$ & $\begin{array}{l}-0.18 \\
(-0.47)\end{array}$ \\
\hline Büyüme & $\begin{array}{c}-1.38 * * * \\
(-5.29)\end{array}$ & $\begin{array}{l}1.12^{*} \\
(1.74)\end{array}$ & Büyüme & $\begin{array}{l}-0.13^{* * *} \\
(-4.87)\end{array}$ & $\begin{array}{c}-0.23 * * * \\
(-3.06)\end{array}$ \\
\hline $\begin{array}{l}\text { Etnik } \\
\text { Çeşitlilik }\end{array}$ & $\begin{array}{c}0.09 \\
(0.52)\end{array}$ & $\begin{array}{l}2.01^{*} \\
(2.44)\end{array}$ & Eınik Çeşitlilik & $\begin{array}{c}0.90^{* * *} \\
(3.85)\end{array}$ & $\begin{array}{l}4.99^{* *} \\
(1.96)\end{array}$ \\
\hline $\begin{array}{l}\text { Demokrasi²* } \\
\text { Etnik Çeşit. }\end{array}$ & $\begin{array}{c}0.10^{* * *} \\
(2.79)\end{array}$ & $\begin{array}{l}-0.36^{*} \\
(-2.17)\end{array}$ & $\begin{array}{l}\text { Demokrasi }{ }^{2 *} \text { Enik } \\
\text { Ceş̧itlitik }\end{array}$ & $\begin{array}{l}-086^{*} \\
(-1.77)\end{array}$ & $\begin{array}{l}-1.05 * * \\
(-2.37)\end{array}$ \\
\hline $\begin{array}{l}\text { Demokratikle } \\
\text { sme } \\
\text { *Etnik Çes. }\end{array}$ & $\begin{array}{l}-0.06^{*} \\
(-2.07)\end{array}$ & $\begin{array}{l}-0.09 \\
(-1.16)\end{array}$ & $\begin{array}{l}\text { Demokratikleşme } \\
{ }^{*} \text { Etnik Çes.. }\end{array}$ & $\begin{array}{c}-0.02 \\
(0.65)\end{array}$ & $\begin{array}{c}-0.44 * * * \\
(-3.19)\end{array}$ \\
\hline Nüfus $(80-89)$ & $\begin{array}{l}0.46^{* * *} \\
(12.86)\end{array}$ & $\begin{array}{c}0.24^{* * *} \\
(2.86)\end{array}$ & Nüfus $90-99$ & $\begin{array}{l}0.39 * * * \\
(11.13)\end{array}$ & $\begin{array}{c}0.62^{* * *} \\
(3.13)\end{array}$ \\
\hline $\begin{array}{l}\text { Bölgesel } \\
\text { Kuklalar }\end{array}$ & Evet & Evet & Bölgesel Kuklalar & Evet & Ever \\
\hline Pseudo. $\mathrm{R}^{2}$ & 0.27 & 0.33 & Pseudo. $\mathrm{R}^{2}$ & 0.39 & 0.55 \\
\hline Gözlem sayısı & 105 & 105 & Gözlem sayısı & 106 & 106 \\
\hline
\end{tabular}

Not: $z$ istatistikleri parantez içinde gösterilmiștir. $\quad{ }^{*} p<0.10,{ }^{* *} p<0.05, * * * p<0.01$

Tablo 2, şiddet yoğunluğunun/derecesinin 1990'lı ylllarda politik değişkenlere de bağlı olduğunu göstermektedir. Ayrıca etnik çeşitlilik 1990'lı yıllarda, şiddet yoğunluğunu istatistiksel olarak anlamlı bir şekilde etkileyen bir faktördür. 1980'li yıllarda etnik çeşitliliğin etkisinden çok emin olunamazken, 1990'lı yıllarda, kullanılan her iki veri kaynağı için de, etnik çeşitliliği yüksek olan toplumlarda, şiddetin yoğunluğu da daha yüksek olmuştur.

Ekonomik olarak entegre olan dünyada kültürel ve politik olarak bir ayrışma gözlenmektedir. 1980'li yıllar için çekilen regresyonda, demokrasi ve 
demokratikleşme değişkenleri şiddet yoğunluğunu etkilememektedir. 1980'li ylllarda, şiddet yoğunluğunu etkileyen faktör ekonomik gelişmişlik düzeyidir. 1990'lı yıllarda ise şiddet yoğunluğu, ekonomik değişkenlerden etkilendiği gibi demokrasi değişkeni tarafından da etkilenmektedir. Demokrasi ile şiddet yoğunluğu arasında doğrusal olmayan bir ilişki vardır. Düşük demokrasi ve çok yüksek demokrasi seviyeleri için şiddet yoğunluğu düşük, orta düzey demokrasi seviyeleri için şiddet yoğunluğu yüksektir. Çok düşük demokrasi seviyelerinin hakim olduğu, diktatörlüklerin ya da askeri rejimlerin olduğu dönemlerde şiddet yoğunluğunun az olması anlaşılır bir durumdur çünkü şiddet başlamadan bitirilmiştir. Çok yüksek demokrasi seviyelerinde ise şiddetin ekonomik ve politik maliyeti yüksek olabileceğinden, hiçbir grup bu maliyete katlanmak istemeyebilir. İlginç olan bir bulgu da, 1990'lı yıllarda, etnik çeşitliliğin çok olduğu ve yüksek demokrasi seviyelerine sahip ülkelerde, şiddet yoğunluğunun düşük olduğudur. İktisadi büyüme şiddet yoğunluğunu, 1990'li yıllar için, kesinlikle azaltıcı yönde etkilemektedir; daha hızlı büyüyen toplumlarda ceteris paribus daha düşük yoğunluklu şiddet gözlenmektedir.

Tablo 2'den çıkarılabilecek en önemli sonuç şudur: Etnik çeşitlilik ve demokrasi değişkenlerinin, 1990'lı yıllardaki şiddetin yoğunluğunda ,1980'li yıllarla karşılaştınldığında, daha önemli rol oynadıklannı görüyoruz. Etnik çeşitlilikler şiddet yoğunluğunu arttırıcı bir etkiye, demokrasi ise doğrusal olmayan bir etkiye sahiptir. Orta düzey demokrasi seviyelerine sahip ülkelerde ise, şiddet yoğunluğu daha yüksektir. Etnik çeşitliliklerin, şiddet yoğunluğunu arttırıcı bir etkiye sahip olması, etnik temizleme ya da etnik bölünme sonucunu doğurmamalıdır; çünkü bu ikisinin etnik şiddeti ortadan kaldırmadığını gösteren çalışmalar yayımlanmıştır (Sambanis, 1999).

Kamu harcamalarının boyut ve kompozisyonu ve bunların etnik çeşitlilik ve politik şiddet tarafından nasıl etkilendiğini gösteren regresyon sonuçlan ise Tablo 3'de gösterilmiştir. 
Tablo 3 Kamu Harcamalarl ve Demokrasi Sistem Tahmini

\begin{tabular}{|c|c|c|c|c|c|c|}
\hline \multicolumn{7}{|c|}{ Sistem Tahmini (SUR) } \\
\hline Değişkenler & $\begin{array}{l}\text { Gayri Safi } \\
\text { Tüketim } \\
\text { Harcaması }\end{array}$ & $\begin{array}{l}\text { Askeri } \\
\text { Harcamal } \\
\text { ar }\end{array}$ & $\begin{array}{l}\text { Net } \\
\text { Tüketim } \\
\text { Harcamalan }\end{array}$ & $\begin{array}{l}\text { Egitim } \\
\text { Harcamalan }\end{array}$ & $\begin{array}{l}\text { Sağlık } \\
\text { Harcamalan }\end{array}$ & $\begin{array}{l}\text { Demokras } \\
\mathrm{i}\end{array}$ \\
\hline Sabit & $\begin{array}{c}0.19 \\
(0.32)\end{array}$ & $\begin{array}{c}-0.69 \\
(-0.45)\end{array}$ & $\begin{array}{c}0.23 \\
(0.29)\end{array}$ & $\begin{array}{c}-0.54 \\
(-0.91)\end{array}$ & $\begin{array}{l}-1.13^{*} \\
(-1.81)\end{array}$ & $\begin{array}{c}4.09 * * * \\
(6.49)\end{array}$ \\
\hline Siddet & $0.03 *$ & $0.08^{* *}$ & 0.01 & 0.01 & 0.01 & 0.02 \\
\hline Yoğunluğu & $(1.93)$ & $(2.03)$ & $(0.47)$ & $(0.54)$ & $(0.25)$ & $(0.93)$ \\
\hline GSMH & $\begin{array}{r}0.26^{* * * *} \\
(6.97)\end{array}$ & $\begin{array}{c}0.13 \\
(1.49)\end{array}$ & $\begin{array}{c}0.31^{* * *} \\
(5.09)\end{array}$ & $\begin{array}{c}0.27^{* * * k} \\
(5.96)\end{array}$ & $\begin{array}{c}0.30^{* * *} \\
(6.24)\end{array}$ & $\begin{array}{c}-0.35 * * * \\
(-5.32)\end{array}$ \\
\hline Nüfus & $\begin{array}{c}-0.02 \\
(-0.94)\end{array}$ & $\begin{array}{c}0.01 \\
(0.17)\end{array}$ & $\begin{array}{c}-0.06 \\
(-1.64)\end{array}$ & $\begin{array}{c}-0.04 \\
(-1.40)\end{array}$ & $\begin{array}{c}-0.02 \\
(-0.71)\end{array}$ & $\begin{array}{l}-0.003 \\
(-0.11)\end{array}$ \\
\hline Sehirleşme & & & & & & $\begin{array}{c}0.12 \\
(0.97)\end{array}$ \\
\hline Eınik Farklılık & $\begin{array}{l}0.004 \\
(0.12)\end{array}$ & $\begin{array}{c}-0.03 \\
(-0.42)\end{array}$ & $\begin{array}{c}0.06 \\
(1.00)\end{array}$ & $\begin{array}{c}-0.03 \\
(-0.68)\end{array}$ & $\begin{array}{l}-0.08^{*} \\
(-1.80)\end{array}$ & $\begin{array}{c}0.03 \\
(0.70)\end{array}$ \\
\hline Dıs Ticaret & $\begin{array}{l}0.11^{* *} \\
(2.26)\end{array}$ & $\begin{array}{c}-0.05 \\
(-0.33)\end{array}$ & & & & \\
\hline $\begin{array}{l}\text { Bölgescl } \\
\text { Kuklalar }\end{array}$ & Evet & Evet & Evet & Evet & Evel & Evet \\
\hline Duzeltilmis $\mathrm{R}^{2}$ & 0.36 & 0.31 & 0.18 & 0.36 & 0.56 & 0.60 \\
\hline Gözlem Sayısı & 107 & 101 & 99 & 107 & 107 & 108 \\
\hline
\end{tabular}

Not: $\mathrm{t}$ istatistikleri parantez içinde gösterilmiştir, ${ }^{*} \mathrm{p}<0.1,{ }^{* *} \mathrm{p}<0.05,{ }^{* * *} \mathrm{p}<0.01$

Tablo 3 çeşitli kamu harcamaları ile demokrasi değişkenini aynı anda bir sistem olarak tahmin eden regresyon sonuçlarını vermektedir. Tablodan da görüldügüu gibi etnik farklılık/çeşitlilik sağlık harcamaları dışında diğer harcamalar üzerinde belirleyici bir etkiye sahip değildir. Etnik farkılığın kamu hizmetlerine olan tercihleri etkileyebileceği ve dolayısıyla da kamu harcamalarının boyutunu etkileyebileceği teorik olarak anlamil olsa da, uygulamada bu bağlantı ortaya çıkmamaktadır. Kamu sağlık harcamalarının, etnik farklılığı yüksek olan ülkelerde milli gelirden aldığı pay, diğer ülkelere göre daha düşüktür. Bu durum bu ülkelerde sağlık hizmetlerinin düşüklüğü anlamına gelmemektedir çünkü bireyler kendi sağlık harcamalarına katlanıyor anlamina da gelebilir.

Şiddet yoğunluğu sadece askeri harcamalarla gayri safi tüketim harcamaları üzerinde pozitif yönde bir etki yapmaktadır. Bu aslında beklenen 
bir durumdur; şiddet yoğunluğu askeri harcamaları arttırmaktadır. Aynı zamanda genel idare hizmetlerini gösteren gayri safi harcamalar üzerinde de arttırıcı bir etkiye sahiptir. Kişi başına düşen milli gelir, askeri harcamalar dışında. diğer bütün harcamaları arttıncı bir etkiye sahiptir; ki bu da Wagner yasası gereği beklenen bir durumdur. Askeri harcamaların en önemli belirleyicisi olarak şiddet yoğunluğunu görmekteyiz. Daha yüksek şiddete maruz kalan ülkeler, askeri harcamalara diğer ülkelere göre daha çok kaynak ayırmaktadırlar.

Demokrasi regresyonu ise, etnik farklılığın demokrasi üzerinde önemli bir etkiye sahip olmadığını göstermektedir. Etnik farklılığı yüksek olan ülkelerde daha az demokrasi ya da çok demokrasi vardır yargısına ulaşamıyoruz. Diğer bir bulgu ise, ekonomik gelişmişlik derecesinin demokrasiyi olumlu ve anlamlı bir şekilde etkilediğidir. Daha çok demokrasi için, daha çok ekonomik gelişmişlik düzeyi gerekmektedir.

\section{Sonuç ve Tartışma}

Bu çalışmada politik şiddet, etnik ve kültürel çeşitlilik ve kamu harcamalarının boyut ve kompozisyonu arasındaki ilişki araştırılmıştır. Konu, tartışmaya yeni açılmıştır ve literatür yeni oluşmaktadır. Bu anlamda, çalışmamız, önemli bir boşluğun varlığına işaret etmekte ve bu boşluğun doldurulması için mütevazi bir katkı yapmayı amaçlamaktadır.

Yukarıda sıralanan değişkenler arasındaki ilişki 1980 ve 1990'lı yıllar karşılaştınlarak incelenmektedir. 1980'li yıllarda, etnik ve kültürel çeşitlilik, şiddeti başlatan önemli öğeler arasında değildir. Bu ylllarda, ekonomik değişkenler şiddet başlangıcı için daha önemlidir. Çok fakir ve çok zengin ülkelerde şiddet başlaması diğer ülkelere oranla daha azdır.

1990'lı yıllarda ise durum değişmiştir. Ekonomik değişkenler şiddet başlangıcı için artık önemli değildir. Demokratikleşme ve etnik çeşitlilik değişkenleri, şiddet başlangıcı için daha önemli olmuştur. Etnik çeşitliliği yüksek olan ülkelerde daha çok şiddet başlangıcı gözlenmektedir. Ayrıca bu dönemde, demokratikleşmenin az olduğu ülkelerde de, daha çok şiddet başlangıcı görülmektedir. Şiddet başlangıcından öte 2000'li yıllar için, politik istikrarın belirleyicileri de analiz edilmiştir. Buna göre, 2000'li yıllarda, ekonomik değişkenlerin değil, politik ve kültürel öğelerin daha önemli olduğu, demokrasinin çok az ve çok fazla olduğu ülkelerin daha çok politik istikrara sahip bulunduğu ve etnik çeşitliliğin politik istikrarı azaltıcı bir etki yaptığı sonucu ortaya çıkmaktadır. 
Politik şiddetin başlamasından öte, şiddetin yoğunluğu/derecesini etkileyen faktörler de araştırılmışır. Burada 1980'li yıllarda, sadece ekonomik faktörler önemli iken, 1990'l yıllarda politik ve kültürel faktörler daha önemli olmuştur. Burada da şiddet başlamasında görülen eğilimler, şiddetin yoğunluğunda da görülmektedir. Demokrasinin çok az ve çok fazla olduğu ülkelerde şiddetin yoğunluğu daha azdır. Öte yandan etnik çeşitliliği yüksek olan ülkeler daha çok şiddet yoğunluğuna sahne olmuştur.

Kamu harcamalannın kompozisyonu da incelenmiştir. Şiddet yoğunluğu, sadece genel idare hizmetleri harcamalannın ve askeri harcamaların artmasına neden olmuştur. Etnik farklılıklar ise şiddet yoğunluğunu belirleyen faktörlerden biri iken, kamu harcamalarının belirlenmesinde sağlık harcamalan dışında önemli olmamaktadır. Demokrasi etnik çeşitlilikten etkilenmeyen bir faktör olarak ortaya çıkmaktadır.

Bu çalışmada, yeni oluşan literatüre katkıda bulunmak amaçlanmıştır. $\mathrm{Bu}$ konuda, ileride yapılması gereken çalışmalar arasında, sıfırı yüksek saymaca model tahmin yönteminin kullanılması, regresyon sonuçlarının kuvvetliliğini test etmek açısından oldukça önemlidir. Ayrıca kültürel çeşitlilik indekslerinin yenilenmesi ya da farkh indekslerin regresyonlarda test edilmesi de önemli boşlukları dolduracaktır.

\section{Kaynakça}

ADOISON, T / MURSHED, M. (2005), "Transnational Terrorism as a Spillover of Domestic Disputes in Other Countries," Defense and Peace Economics, Vol.16, No. 2: 69-82.

AKDEDE, S. H. (2006), "Devletlerin Bölünmesinin Ekonomik ve Politik Yükü," Iktisat-Isletme ve Finons, Yll 21, Sayı 242: 81-91.

ALESINA, A. / LA FERRARA, E .(2004), "Ethnic Diversity and Economic Performance," NBER Working Paper, No. 10313, February.

ALESINA, A./ OZLER, \$./ROUBINI, N./ SWAGEL, P. (1996), "Political Instability and Economic Growth," Journol of Economic Growth, Vol. 1, No. 2: 189-211.

ALESINA, A./SPOLAORE, E./WACZIARG, R. (1997), "Economic Integration and Political Disintegration," NBER Working Paper, No. 6163, July.

ALESINA, A. /WACZIARG, R. (1998), "Openness, Country Size, and Government" Journal of Public Economics, 69: 305-321.

ANNETT, A. (2001), "Social Fractionalization, Political Instability, and the Size of Government," IMF Staff Papers, Vol. 48, No. 3: 551-592.

COLLIER, P./HOEFFLER, A. (2006), "Military Expenditures in Post Conflict Societies," Economics of Governance, 7: 89.107.

EASTERLY, W. (2000), "Can Institutions Resolve Ethnic Conflict," Policy Research Working Paper, No. 2482, The World Bank.

ELLINGSEN, T. (2000), "Colorful Community or Ethnic Witches' Brew? Multiethnicity and Domestic Conflict During and After the Cold War," Journal of Conflict Resolution, 44 (April): 228-249. 
FEARON, J. (2003), "Ethnic and Cultural Diversity by Country," Journal of Economic Growth, 8:195-222.

FEARON, J./DAVID, L. (2001), "Ethnicity, Insurgency, and Civil War," Mimeo, Stanford University.

GUNDLACH,E./MATUS-VELASCO, X. (2000), "Climatic Conditions, Cultural Diversity and Labor Productivity," Kiel Working Paper, No. 1015, December.

KRUEGER, A.B. /MALECKOVA, J. (2002), "Education, Poverty, Political Violence and Terrorism: is There a Causal Connection?," NBER Working Paper, No. 9074, July.

LI, Q. I SCHAUB, D.(2004), "Economic Globalization and Transnational Terrorism," Journal of Conflict Resolution, Vol.48, No.2: 230-258.

MINIER, A.J. (2003), "Democrats, Dictators, and Demonstrators," Economic Inquiry, Vol.41, No.2: 224-233.

MONTALVO, J.G. / REYNOL-QUEROL, M. (2005), "Ethnic Diversity and Economic Development," Journal of Development Economics, 76: 293-323.

MOUSSEAU, D.Y. (2001), "Democratizing with Ethnic Divisions: A Source of Conflict ?," Journal of Peace Research, Vol.38, No.5: 547.567.

OKEDIJI, O.T. (2005), "The Dynamics of Ethnic Fragmentation A Proposal for an Expanded Measurement Index," The American Journal of Economics and Sociology, Vol. 64, No. 2: 637-662.

REYNOL-QUEROL, M. (2005), "Does Democracy Preempt Civil Wars ?", European Journal of Political Economy, Vol.21: 445-465.

SAMBANIS, N. (1999), "Ethnic Partition as a Solution to Ethnic War: An Empirical Critique of the Theoretical Literature," Policy Research Working Paper, No. 2208, The World Bank.

TARZWELL, G. (2003), "The Impact of Diverse Preferences on Government Expenditures," Applied Economics Letters 10: 695-699. 